\title{
EDITORIAL
}

\section{A BALANCING ACT: EDITORIAL INDEPENDENCE VERSUS THE NEED OF PROFESSIONAL SOCIETIES TO PUBLISH OUTPUTS}

\author{
A.J. SINCLAIR 1 , B. VELLAS² \\ 1. Geriatric and Diabetes Research Centre, The University of Bedfordshire, Luton, United Kingdom; 2. Gérontopôle, U 558, Alzheimer's Disease Clinical Research Center, CHU \\ Toulouse, France, E-mail: vellas.b@chu-toulouse.fr \\ The autors and the editors retracted this article from publication in March 2009 by mutual agreement. \\ Publication was caused by an inadvertent breakdown in the operational work flow from JNHA to Springer.
}

